\title{
REESTRUTURAÇÃO DA POLÍTICA DE CONTEÚDO LOCAL NA INDÚSTRIA DO PETRÓLEO SOB ÓTICA CONSTITUCIONAL DO DESENVOLVIMENTO NACIONAL
}

\section{RESTRUCTURING LOCAL CONTENT POLICY IN THE OIL INDUSTRY FROM THE CONSTITUTIONAL PERSPECTIVE OF NATIONAL DEVELOPMENT}

Guilherme Marinho de Araújo Mendes ${ }^{1}$

Fabrício Germano Alves ${ }^{2}$

\begin{abstract}
RESUMO: O presente artigo tem por fim discutir a estruturaçăo da política de conteúdo local no setor do petróleo e como esta política possui o respaldo nos objetivos constitucionais do desenvolvimento e reduçăo das desigualdades. Dentre os objetivos fundamentais da República previstos na Constituiçăo Federal, o desenvolvimento nacional e a reduçâo das desigualdades regionais foram os pilares para a formulaçáo da política de conteúdo local nas atividades do petróleo aplicada desde 1999, data da abertura da exploraçăo petrolífera pelo setor privado (Rodadas de licitaçăo). Sob a promessa de avanço tecnológico, aumento de produtividade, ampliaçấo e competitividade da indústria nacional, melhoria na infraestrutura, criaçăo de emprego e renda, dentre outros progressos, foi criada uma política de reserva de mercado, tentando de alguma forma repetir o sucesso de aplicaçăo da Noruega, Reino Unido e Coreia do Sul. O estudo foi desenvolvido através do método hipotético-dedutivo, de abordagem qualitativa e a conclusâo aferida foi no sentido de uma reestruturaçáo da política de conteúdo local. Apesar dos avanços, há críticas e problemas graves identificados na formulaçâo e aplicaçâo, de maneira que, diante do cenário de reduçâo da política e incertezas, é necessário repensar o modelo atual e apresentar novas propostas comtemplando o que determina a Constituiçăo Federal.
\end{abstract}

Palavras-chave: Conteúdo local. Petróleo. Desenvolvimento. Constituiçăo Federal.

\footnotetext{
1 Mestrando em Direito pela Universidade Federal do Rio Grande do Norte - UFRN, Mestrando em Cogniçáo, Tecnologia e Instituiçoes pela UFERSA, pós-graduado lato sensu em Direito e Processo do Trabalho pela Faculdade de Direito Damásio de Jesus, Bacharel em Direito pela Universidade Potiguar. É professor substituto de Direito da UFERSA 2017-2019. guilhermemarin@outlook.com

2 Doutor em Sociedad Democrática, Estado y Derecho pela Universidad del País Vasco / Euskal Herriko Unibertsitatea (UPV/EHU) - Espanha. Mestre em Direito pela Universidade Federal do Rio Grande do Norte (UFRN). Especialista em Direito do Consumidor e Relaçôes de Consumo pela Universidade Potiguar (UNP). Especialista em Docência no Ensino Superior pelo Centro Universitário das Faculdades Metropolitanas Unidas (FMU). Graduado em Direito pela Universidade Potiguar (UNP). Professor da Graduaçáo e Pós-Graduaçăo da Universidade Federal do Rio Grande do Norte (UFRN). Líder do Grupo de Pesquisa Direito, Estado e Sociedade. Avaliador do INEP/MEC. fabriciodireito@gmail.com
} 
ABSTRACT: This article aims to discuss the structuring of the local content policy in the oil sector and how this policy has or respect the constitutional goals of development and reduction of inequalities. Among the fundamental objectives of the Republic foreseen in the Constitution, national development and the reduction of regional inequalities were the pillars for a policy of local content policy applied in oil activities from 1999, given the exploitation possibility of the oil industry by the private sector (Bidding Rounds). Under a promise of technological advancement, increased performance, expansion and performance of the national industry, infrastructure improvement, job and income creation, among other advances, a market reserve policy was created, trying somehow repeated or the success of the application. The study was developed through the hypothetical-deductive method, with qualitative approach and the conclusion reached was a restructuring of the local content policy. Despite advances, there are critical and serious problems that can be applied and applied, so that, given the scenario of policy reduction and uncertainties, reimbursement or current model and presents the new versions included or excluded from the Constitution.

Keywords: Local content. Petroleum. Development. Federal Constitution.

\section{INTRODUÇÃO}

O início da exploraçâo do petróleo no Brasil é marcado pelo monopólio da Uniâo e operacionalizado pela estatal "Petróleo Brasileiro S.A" (Petrobras) criada pelo entâo presidente Getúlio Vargas, em 03 de outubro de 1953 (SANÁBIO, 2009).

Todavia, em 1995 foi promulgada a Emenda Constitucional n 9 a qual previa a possibilidade de atuaçâo de empresas privadas nas atividades de petróleo e gás natural, representando a flexibilizaçăo do monopólio do Estado efetivada em 1997 através da Lei 9.478/97 (Lei do Petróleo).

A abertura para a possível exploraçấo do setor privado veio acompanhada da criaçăo da Agência Nacional do Petróleo, Gás Natural e Biocombustíveis (ANP) para realizar as rodadas de licitaçáo (agente regulador do setor) e a formulaçáo da política de conteúdo local para desenvolver a indústria nacional.

As próprias atividades do petróleo criam um conjunto de demandas as quais sâo atendidas pela soma da produçáo de diversos bens e oferecimento de diversos serviços, ou seja, uma cadeia produtiva.

Conteúdo local é o instrumento que garante uma participaçăo mínima da indústria brasileira, por consequência, movimenta a economia regional e local, na fase de desenvolvimento e exploraçāo do petróleo através do suprimento da demanda de bens e serviços das atividades relacionadas às tais fases. Trata-se de uma obrigaçăo contratual da empresa vencedora da licitaçăo (ANP, 2018).

Há claramente o fundamento constitucional para justificar a política de conteúdo local: os objetivos fundamentais da República quanto ao desenvolvimento nacional e reduçăo das desigualdades regionais (via desenvolvimento regional) como disposto no art. $3^{\circ}$.

A cada realizaçâo, as rodadas de licitaçâo promovidas pela ANP envolvem bilhôes de reais em investimentos empregados no petróleo brasileiro. A título 
ilustrativo, na $12^{\mathrm{a}}$ Rodada de Licitaçōes, a porcentagem do conteúdo local atingiu a média 72,61\% na fase de exploraçâo, e de $84,47 \%$ para a de desenvolvimento. De acordo com registros da ANP, no período compreendido entre 2009 e 2012, investimentos direcionados no conteúdo local totalizaram 16,3 bilhōes de reais (CHAMBRIARD, 2013).

Apesar dos avanços promovidos pelas décadas de aplicaçấo da política de conteúdo local, os fins pretendidos săo questionados uma vez que estudos sobre o setor (inclusive por órgâos oficiais como TCU e Senado Federal) apontam a existência de graves problemas de competitividade (preço, prazo superior ao mercado internacional e falta de tecnologia), eficiência, insegurança jurídica e forte caráter punitivista.

Os problemas de eficiência da indústria nacional fazem as petroleiras buscarem a ANP para revisar as obrigaçōes contraídas no contrato e evitar o pagamento das multas pelo descumprimento dos percentuais assumidos.

No âmbito da OMC, há fortes questionamentos sobre esse tipo de política intervencionista, até mesmo para evitar distorçôes do mercado. Em contrapartida, na seara internacional, os casos da Noruega, Reino Unido e Coreia do Sul servem como exemplo de sucesso de aplicaçăo desse tipo política, apesar de ter sido vigente outrora, os efeitos da aplicaçâo permitiram a consolidaçấo da indústria nacional desses países e a competitividade em nível internacional.

A política de conteúdo local passa por constantes alteraçōes: agora a incidência sobre a demanda é global ao invés da vasta gama de itens e subitens, os percentuais obrigacionais foram reduzidos e cada vez mais há o clamor pela possibilidade de isentar a exigência; maior flexibilidade e simplificaçăo (ANP, 2017).

As falhas apontadas e a crise da Petrobras nos últimos anos fizeram a política de conteúdo local ser tema de debate, reflexóes e revisâo.

No Poder Legislativo tramita propostas de lei para positivar disciplina legal, transparente, adequada e delimitadora ao tema, diversamente do tratamento atual composto por um complexo extenso de normas editadas pelos órgáos do Executivo.

Nesse cenário, a Constituiçâo Federal, norma suprema fruto da soberana vontade popular e projeto maior da sociedade brasileira, deve ser o Norte para solucionar os entraves verificados.

\section{A INDÚSTRIA DO PETRÓLEO E O CONTEÚDO LOCAL}

O art.177 da Constituiçăo Federal estabelece nos incisos de I ao IV que as atividades referentes ao petróleo e gás natural (lavra e pesquisa de jazidas, refino, importaçâo e exportaçâo) constituem monopólio da Uniâo. Entretanto, a ediçâo da Emenda Constitucional n 9 de 1995 conferiu uma flexibilizaçăo neste monopólio possibilitando à Uniăo contratar empresas estatais ou privadas para exercer as atividades descritas nos incisos do art. 177 da Constituiçăo Federal (teor do $§ 1^{\circ}$ deste dispositivo).

Na atualidade, a contrataçăo envolvendo a exploraçâo do petróleo no Brasil obedece 
o regime jurídico de concessăo regulamentado pela Lei nº 9.478/1997 (Lei do Petróleo), ao regime de Partilha da Produçáo regulamentado pela Lei ${ }^{\circ} 12.351 / 2010$, ou ao regime de cessâo onerosa previsto na Lei $n^{\circ} 12.276 / 2010$. O primeiro diploma trata-se do regime geral, enquanto o segundo versa sobre as áreas específicas do Pré-sal. Já o terceiro regula a cessâo onerosa da Uniâo à Petrobras S.A., dispensada a licitaçăo, de determinadas áreas contidas no Pré-sal.

O conceito legal de conteúdo local está disposto no art. $2^{\circ}$, inciso VIII da Lei n¹2.351 de 2010 (Lei do Pré-Sal), a saber:

Art. 2o [...] VIII - conteúdo local: proporçăo entre o valor dos bens produzidos e dos serviços prestados no País para execuçáo do contrato e o valor total dos bens utilizados e dos serviços prestados para essa finalidade;

Embora a lei traga um conceito parecido com uma equaçăo matemática, Luiz Quintans (2010) aborda conteúdo local como sendo uma orientaçâo política, um processo de estímulo com a finalidade de ampliar a capacidade de fornecimento da nacional, desenvolvendo a indústria local de bens e serviços a ponto de obter competitividade em nível internacional, renda, emprega e tecnologia no Brasil. Há uma dimensăo política, um interesse estatal por trás da regulamentaçâo imposta.

A Lei do Petróleo (Lei n 9.478/97) institui como uma das atribuiçôes do Conselho Nacional de Política Energética (CNPE), a criaçâo de políticas nacionais que fomentem o desenvolvimento econômico e tecnológico por meio de Conteúdo Local. Assim está previsto no art. $2^{\circ}$, inciso IX e X da Lei $n^{\circ}$ 9.478/97:

Art. $2^{\circ}$. Fica criado o Conselho Nacional de Política Energética - CNPE, vinculado à Presidência da República e presidido pelo Ministro de Estado de Minas e Energia, com a atribuiçáo de propor ao Presidente da República políticas nacionais e medidas específicas destinadas a: [...] IX - definir a estratégia e a política de desenvolvimento econômico e tecnológico da indústria de petróleo, de gás natural, de outros hidrocarbonetos fluidos e de biocombustíveis, bem como da sua cadeia de suprimento; $\mathrm{X}$ - induzir o incremento dos índices mínimos de conteúdo local de bens e serviços, a serem observados em licitaçôes e contratos de concessáo e de partilha de produçấo, observado o disposto no inciso IX. $\S 1^{\circ}$ Para o exercício de suas atribuiçôes, o CNPE contará com o apoio técnico dos órgáos reguladores do setor energético.

Impende destacar que o dispositivo que trata pontualmente da política de incremento dos índices mínimos de conteúdo local foi acrescido pela Lei do Pré-Sal (como anteriormente mencionado, em 2010). Antes da criaçâo dessa lei năo havia o inciso X, mostrando assim, uma atençấo mais recente do legislador para políticas de desenvolvimento via conteúdo local. A mesma observaçăo vale para o inciso IX, o qual institui expressamente a atribuiçăo do CNPE para definir a estratégia e a política de desenvolvimento econômico e tecnológico da indústria de petróleo e da sua cadeia de suprimento (essa atribuiçấo também foi inserida da Lei do Pré-sal, no entanto, a Lei $n^{\circ} 12.490 / 2011$, que dispôe sobre variados assuntos, deu nova redaçăo apenas para inserir os biocombustíveis).

Por sua vez, o $\S 1^{\circ}$ do dispositivo citado, demonstra a necessidade de açóes integradas entre o CNPE e ANP (órgâo regulador) para que as políticas públicas, dentre as quais se destaca a de conteúdo local, seja algo efetivo e a finalidade de desenvolvimento seja alcançada. 
A ANP é uma autarquia especial que além de possuir a atribuiçăo de contratar e elaborar editais licitatórios (Brasil Rounds), também regulamenta e fiscaliza a indústria do petróleo, gás natural, derivados e biocombustíveis (art. $8^{\circ}$ da lei 9.478/97).

Desde a Primeira Rodada de licitaçăo (realizada em 1999) a ANP já insere o instituto do conteúdo local nos contratos de concessáo. O compromisso que as empresas que participavam da licitaçáo tinham com o conteúdo local servia como elemento para a ANP avaliar qual seria a melhor proposta. Até a Quarta Rodada era dessa forma: apesar de aplicar no contrato, náo se exigia um porcentual mínimo destinado ao conteúdo local (ANP, 2018). A exigência de uma porcentagem mínima de investimento referente ao conteúdo local só foi instituída na Quinta e Sexta rodadas de Licitaçôes (ANP, 2018).

Em 2005, a ANP criou o Sistema de Certificaçâo de Conteúdo Local que teve aplicaçáo a partir da $7^{a}$ Rodada de Licitaçâo (ainda em vigor em 2019) e está regulamentado principalmente por meio da Resoluçâo n 19 de 2013 (atualizada pela Resoluçáo nº 26 de 2016).

A certificaçāo de conteúdo local é realizada por organismos de certificaçaáo que recebem esse título após um processo administrativo de acreditaçăo junto a ANP, nos termos da Resoluçâo ANP n 25/2016 (antes a certificaçâo era regulamentada pela Resoluçâo ANP n³7/2007, que, embora revogada, permanece com algumas regras válidas para garantir a transiçâo). Esse sistema visa aferir a efetivaçăo de conteúdo local através de relatórios (emitidos pelos organismos de cerificaçăo), subsidiando a comprovaçăo do cumprimento dos percentuais pactuados pelos contratados, no padrâo descrito pela Resoluçâo da ANP n²7/2016. É uma forma de aferiçăo técnica do quanto a indústria local está sendo requisitada.

Dos possíveis fundamentos que justificam essa política intervencionista, no âmbito constitucional, o objetivo fundamental do desenvolvimento nacional (art. $3^{\circ}$, II, CF) e a reduçăo das desigualdades regionais (art. $3^{\circ}$, III, CF) fornecem respaldo para conteúdo local ser aplicado na indústria do petróleo. Uma vez que o petróleo é um bem natural da Uniăo (art. 20, IX, CF), as regras que flexibilizam o monopólio da exploraçăo permitindo a contrataçăo de terceiros, săo regulamentadas visando forte contrapartida ao Estado e maximizaçáo dos ganhos sociais.

\section{DESENVOLVIMENTO ECONÔMICO COMO OBJETIVO CONSTITUCIONAL (ART. $3^{\circ}$, II, CF) E CONTEÚDO LOCAL NO SETOR DO PETRÓLEO}

Nâo obstante o desenvolvimento figurar um valor supremo no preâmbulo da Constituiçăo Federal, constitui um objetivo fundamental da República (art. $3^{\circ}$, II, $\mathrm{CF}$ ). Os objetivos fundamentais da República săo metas que vinculam o poder estatal, com força imediata, criando um dever de atuaçăo. Trata-se de uma missáo do Estado no sentido de efetivar os objetivos republicanos de maneira eficiente através de políticas públicas voltadas ao desenvolvimento (FRANÇA, 2014).

Bulos (2011) assevera que o art. $3^{\circ}$ da Constituiçâo Federal é original, nâo tem correspondência com nenhum outro preceito nas Constituiçōes anteriores, uma ideia inédita na ordem constitucional brasileira com inspiraçăo no modelo português (art. $9^{\circ}$ da Constituiçâo lusa).

A necessidade de concretude gera a reivindicaçăo social à realizaçăo de 
políticas públicas, com legitimidade constitucional, importa na prestaçâo positiva do Estado à sociedade, uma imposiçâo de atuaçáo estatal (GRAU, 2010). A transformaçăo de cenário năo se dá pelo simples impulso do mercado, é preciso coordenaçấo e conduçấo de políticas de planejamento que viabilizem a promoçấo do desenvolvimento, exigindo um projeto político apoiado na mobilizaçâo de recursos sociais (FURTADO, 2000).

Năo se pode entender o fenômeno do desenvolvimento como apenas crescimento econômico. O crescimento econômico é apenas uma parcela integrante da noçấo de desenvolvimento: enquanto o primeiro fenômeno versa sobre aspectos quantitativos, o segundo engloba também aspectos qualitativos (GRAU, 2010). No desenvolvimento há uma elevaçăo do nível cultural-intelectual comunitário e um processo de mudança social.

Nas Constituiçôes anteriores, o desenvolvimento tinha estrita ligaçâo com a ordem econômica, no entanto, na Constituiçăo Federal de 1988 a previsâo como objetivo fundamental da república resulta em abranger todas as dimensôes (SILVA, 2010). Para o autor, o crescimento econômico sem justiça social nâo representa um real desenvolvimento, pois falta a participaçăo do povo no fenômeno, melhoria na qualidade de vida e transformaçăo: o desenvolvimento além do aspecto econômico (com distribuiçăo justa), possui a dimensăo social, cultural e política, cominando no contínuo incremento do bem-estar da populaçăo e participaçăo ativa (SILVA, 2010).

Na concepçăo de Amartya Sen (2008), desenvolvimento é visto como liberdade. A expansâo da liberdade é o principal meio para atingir o desenvolvimento, ao mesmo tempo que é o objetivo prioritário do fenômeno.

Para Sen (2008), analisar o desenvolvimento significa avaliar o alargamento da liberdade das pessoas (avaliaçăo), já que o fenômeno depende da liberdade das pessoas (eficácia). A liberdade importa na capacidade de atuaçâo política e econômica, condiçâo necessária para o funcionamento da democracia em um cenário de oportunidades sociais igualitárias, equilíbrio na distribuiçâo de renda, garantia, alimentaçâo, saúde, educaçâo e bem-estar social, ausência de privaçăo (SEN, 2008).

Em contrapartida, cenários de escassez, doenças, mortes prematuras, subnutriçăo, pobreza, baixo índice de alfabetizaçăo, restriçôes na participaçăo política, privaçôes das potencialidades individuais caracterizam naçôes de baixo grau de desenvolvimento (SEN, 2008).

A política de conteúdo local tem a funçăo de auxiliar na concretizaçâo dos objetivos constitucionais previstos especificamente nos incisos do artigo $3^{\circ}$ da Constituiçáo Federal, por meio de uma açăo voltada para o fomento da indústria nacional com aporte ao desenvolvimento econômico e social. Esta seria a validaçấo da política criada pela ANP (FABRÍCIO, 2014).

O Estado realiza a intervençăo indireta na forma de regulamentaçăo e fiscalizaçáo da economia, ou seja, se torna um agente normativo ou regulador para a concretizaçăo de objetivos sociais. A previsăo constitucional desse tipo de intervençăo está no art. 174 e do conteúdo deste dispositivo é possível extrair que a intervençăo indireta ocorre de três formas: através da fiscalizaçâo, do incentivo e do planejamento (CABRAL, 2008). A política de conteúdo local no setor do petróleo foi formulada com a justificativa constitucional do desenvolvimento e assume as três dimensōes de intervençăo. 


\section{DESENVOLVIMENTO REGIONAL E CONSTITUIÇÃO: A REDUÇÃO DAS DESIGUALDADES REGIONAIS (ART. $3^{\circ}$, III, CF)}

O legislador Constituinte de 1988 sistematiza sua preocupaçấo quanto às disparidades entre as regióes brasileiras a ponto de tornar a reduçăo das desigualdades regionais uma das finalidades primordiais. A reduçâo das desigualdades sociais e regionais constitui um dos objetivos fundamentais da República Federativa do Brasil como prescreve o art. $3^{\circ}$, III da Constituiçăo Federal.

Em um país subdesenvolvido sempre há o contraste da coexistência de um polo rico e de um polo pobre, há a realidade de um desequilíbrio econômico e de desarticulaçâo social. Nesse cenário, o processo de desenvolvimento implica na progressiva eliminaçăo das desigualdades sociais, sendo algo programado e voluntário, ou seja, de programaçáo de políticas públicas a longo prazo (COMPARATO, 1989).

O subdesenvolvimento pode ser caracterizado como um desiquilíbrio na assimilaçăo dos avanços tecnológicos, uma desarticulaçâo entre fatores de produçáo e o consumo náo democratizado (apenas concentrado na elite, uma simples modernizaçáo). Logo, o desenvolvimento deve incrementar a eficácia do sistema social de produçăo, a satisfaçâo de necessidades elementares da populaçăo e a efetivaçăo de objetivos almejados pela sociedade (FURTADO, 2000).

O Brasil deixa muito a desejar no que tange ao desenvolvimento, mesmo sendo uma das naçôes mais ricas do mundo. Indicadores sociais brasileiros como saúde, educaçăo, moradia, saneamento básico, estâo consideravelmente abaixo de países com semelhante renda per capita. No Brasil, há uma extrema desigualdade de riqueza, de renda anual e de oportunidade entre brasileiros (FEIJÓ, 2007).

Năo obstante a sistematizaçăo da reduçăo das desigualdades regionais e sociais como objetivos fundamentais da República, o legislador Constituinte insere no corpo da Constituiçăo Federal, essas reduçôes como um dos princípios gerais da atividade econômica, consoante o art. 170, inciso VII.

Os princípios do art. 170 consagram a chamada constituiçăo econômica (MORAES, 2007). O princípio contido no inciso VII do art. 170 da Constituiçăo Federal institui o dever dos atores econômicos, na atividade desenvolvidas por ele, buscar combater as desigualdades, especialmente quando o Estado designa e orienta para reduzir esse problema do país. A existência de desigualdades regionais e sociais atesta a caracterizaçâo do subdesenvolvimento (SZEZERBICKI, 2009).

O desenvolvimento regional tem como pré-condiçăo um processo econômico com o aumento de produtividade e renda em nível local, com sustentabilidade a longo prazo (condiçáo econômica articulada) e um processo social especializado na regionalidade (condiçấo social e ambiental), considerando as peculiaridades culturais, históricas locais (BECKER,; WITTMANN, 2003).

Ricardo Feijó (2007) questiona como um modelo puro de livre mercado poderia chegar a um contexto de distribuiçâao equilibrada, sendo que a desigualdade social é um processo histórico, econômico e político que se perpetua. Por outro lado, em economia mista năo se deve colocar toda responsabilidade pelo combate à pobreza no setor público, devendo ser também suportada pela iniciativa privada (FEIJÓ, 2007). No caso, a regulamentaçăo para 
atingir esse objetivo social também deve recair sobre a indústria do petróleo.

A política de conteúdo local deve ser balizada pelos objetivos constitucionais de promoçâo do desenvolvimento equilibrado do país e de reduçâo de disparidades regionais, através da implementaçâo dentro de parâmetros adequados (FIGUEIREDO, 2016).

\section{CONTEÚDO LOCAL, EXPERIÊNCIA INTERNACIONAL E A OMC}

Países como Reino Unido, Noruega e Coreia do Sul sāo paradigmas de sucesso de aplicaçâo da política de conteúdo local. As décadas de 1960 a 1990 foram marcadas pela intervençăo do Estado no setor de petróleo com a finalidade de priorizar o fornecimento de bens e serviços pela indústria local para suprir as demandas (FORMAN, 2016).

O acúmulo de know-how durante a época de intervençăo estatal permitiu o desenvolvimento industrial a ponto de a indústria competir a nível internacional. A política de conteúdo local permitiu que a indústria se consolidasse e atingisse o fenômeno de desenvolvimento marcado pela sustentabilidade, fortificaçăo da infraestrutura, especializaçăo de mâo-de-obra, inovaçâo e tecnologia. Após a década de 1990, o sentido desses países foi de reduzir a intervençăo, no entanto, a indústria já estava desenvolvida (ALMEIDA, 2015).

O Brasil inicia a inserçâo da política de conteúdo local a partir de 1999, quando há a quebra do monopólio estatal de exploraçăo de petróleo (ocorrida em 1997) e é feita a primeira rodada de licitaçăo dos blocos. Quase contemporânea em relaçăo à experiência brasileira, a Angola começa a intervençăo no ano de 2000 (XAVIER, 2012).

É possível encontrar países que de forma tardia estăo implementando a política de conteúdo local nas suas legislaçôes como México, Cazaquistăo e Nigéria. Entre 2010 e 2015 esses países estăo exigindo percentuais mínimos de conteúdo local com a expectativa de aprender industrialmente com a exploraçăo de petróleo e desenvolver a cadeia de fornecedores locais. Todos esses países tentam de alguma forma se inspirar nos feitos ocorridos na Noruega e demais casos de sucesso (ALMEIDA; LOSEKANN, VITTO, 2016).

No âmbito da OMC, o debate entre países em desenvolvimento e países desenvolvidos sobre investimentos estrangeiros contemplam questionamentos e restriçóes nesse tipo de política industrial. Nos últimos anos a política de conteúdo local foi objeto de grande discussấo nas instâncias nacionais e internacionais, permitindo reflexăo interna sobre quais sâo os benefícios dessas políticas e o que elas têm agregado do ponto de vista econômico e social para o país (FIGUEIREDO, 2016).

\section{DEBATES, CRÍTICAS E REESTRUTURAÇÃO DA POLÍTICA DE CONTEÚDO LOCAL NO SETOR DO PETRÓLEO}

A política de conteúdo local aplicada no Brasil gerou resultados positivos, porém, conforme aponta o Instituto Brasileiro do Petróleo - IBP na agenda prioritária 20192022 (2019) o modelo que exige excessivos e irrealistas níveis de obrigaçôes com base em reserva de mercado gerou efeitos indesejados. Isso porque um modelo composto por reserva de mercado e puniçóes se mostrou ineficaz no fomento do desenvolvimento industrial e um entrave à decisăo de investimento do setor de petróleo. Em 
contrapartida, as recentes reduçóes das exigências de conteúdo local aumentaram a atratividade dos leilóes e destravaram investimentos (IBP, 2019).

O Relatório de Avaliaçăo de Políticas Públicas Comissăo de Assuntos Econômicos do Senado Federal sobre Conteúdo Local (2017) evidencia que fatores como a crise da Petrobras, a queda da cotaçáo do petróleo e o descumprimento dos percentuais de conteúdo local pelas petroleiras, trouxeram a política de conteúdo local para o centro dos debates. Enquanto as petroleiras (inclusive a Petrobras) pugnavam pela simplificaçâo das regras e pela reduçâo dos percentuais mínimos de conteúdo local, a indústria nacional de máquinas e equipamentos pede a manutençăo dos percentuais mínimos por temer a queda da demanda (BRASIL, Senado Federal, 2017).

No debate, o IBP argumenta que a reduçáo do percentual mínimo de conteúdo local seria o suficiente para destravar investimentos e trazer novas oportunidades para o Brasil, principalmente oriundo do capital estrangeiro. A FIESP (Federaçăo das indústrias do Estado de Săo Paulo) e a ABIMAQ (Associaçấo Brasileira da Indústria de Máquinas e Equipamentos) saem em defesa da política de conteúdo local apontando dados negativos sobre a reduçâo de percentuais de conteúdo local, como a flexibilizaçâo enfraquece a indústria local, impactos ínfimos na arrecadaçăo e objetivo intencional de desmantelamento da política (LUMBRERAS; PIQUET, 2018).

O Relatório do Senado Federal (2017) reconhece os resultados alcançados pela aplicaçấo da política de conteúdo local, e mesmo com a importância revelada, afirma que é preciso ajustes tendo em vista as mudanças recentes do setor e as estimativas para a próxima década. Doutra banda, admitir a necessidade de ajustes, náo implica no simples corte radical através da fixaçâo de percentuais mínimos que eliminam a efetividade da política (BRASIL, Senado Federal, 2017).

Apesar da necessidade de ajustes, a política de conteúdo local năo é algo descartável, até mesmo pelo fato de ter fundamento constitucional. Nesse impasse, o que se deve ponderar é a determinaçấo constitucional que o povo soberano determinou como plano social, sendo um desafio a revisăo de uma política de forma que atenda todos os interesses e o desenvolvimento esculpido na Constituiçăo Federal (art. $3^{\circ}$ ).

Os parâmetros de regulaçăo agora năo estăo concentrados apenas no âmbito do Poder Executivo como era tradicionalmente, típicamente no CNPE e na ANP. Projetos de lei já tramitam no congresso pretendendo mudar significativamente a regulaçáo vigente.

\subsection{CRÍTICAS}

A política de conteúdo local vem sofrendo críticas no que tange às exigências de índices náo compatíveis com a realidade, a normatividade complexa e falta de flexibilidade.

Durante esse tempo de aplicaçăo foram identificados problemas dentre os quais é possível destacar: preços excessivamente elevados comparados ao mercado internacional, prazo excessivamente demorado para entregar a demanda de forma que pode afetar a atividade e comprometer cronogramas, inexistência de tecnologia suficiente ou nova tecnologia năo prevista na época da licitaçăo. Ou seja, problemas de competitividade e eficiência comparados ao mercado internacional. 
Uma das bases que serviram para a formulaçāo do Relatório de Avaliaçāo de Políticas Públicas Comissáo de Assuntos Econômicos do Senado Federal sobre Conteúdo Local (2017, p. 37) foi o estudo analítico realizado pelo Tribunal de contas da Uniāo - TCU em 2016, o qual constatou sérios problemas:

Uma auditoria da PCL realizada pelo Tribunal de Contas da Uniâo (TCU) apontou sérios problemas: 1. A PCL náo está atrelada a uma política industrial ampla, náo possui prazo de vigência definido e tem objetivos genéricos, sem metas e métricas que possam mensurar objetivamente seus resultados; 2 . A metodologia de definiçăo e acompanhamento dos índices mínimos de CL é frágil, năo embasada em estudos técnicos; 3. A sistemática da PCL apresenta distorçôes, além de ser complexa e demasiadamente rígida; 4. Existe um alto custo decorrente da política, em funçăo da baixa competitividade da indústria nacional; 5. A ANP ainda năo regulamentou o instrumento de "waiver", causando insegurança jurídica e falta de transparência a um setor de risco já elevado.

A auditoria do TCU também aponta que a política de conteúdo local impóe elevados custos ao setor de petróleo e gás natural (distorçôes no mercado e ineficiência da indústria nacional), elevado número de multas aplicadas pelo descumprimento das obrigaçóes e ausência de prazo estipulado para a sua vigência (BRASIL, Senado Federal, 2017).

As normas instituídas pela ANP determinam que as obrigaçôes de conteúdo local, bem como as obrigaçóes adicionais para fins de pontuaçáo de oferta, devem ser cumpridas integralmente. Caso haja o descumprimento, a multa pode chegar ao valor que seria necessário para atingir o percentual de conteúdo local fixado.

A dificuldade para o cumprimento dos índices de conteúdo local faz a indústria do petróleo buscar o instituto de waiver (isençăo) para revisar os compromissos firmados de conteúdo local.

Segundo a Auditoria Operacional e Avaliaçáo da Sistemática Vigente da Política de Conteúdo Local realizada pelo TCU (2016), multas estimadas podem chegar 25 bilhóes de dólares até 2025 para os projetos em desenvolvimento. Tanto os investimentos quanto os riscos na área petrolífera sâo extremamente altos, e as possíveis multas tornam um fator considerável para aquele que pretende explorar e produzir no Brasil (BRASIL, Tribunal de Contas da Uniăo - TCU, 2016).

Somente em 2018 houve uma regulamentaçăo específica da ANP para definir critérios, requisitos e procedimentos aplicáveis à isençâo de cumprimento da obrigaçăo de conteúdo local, através da Resoluçăo ANP n 726/2018. 0 art. $3^{\circ}$ da Resoluçâo determina que, em caráter excepcional, as hipóteses para pedir a exoneraçâo do compromisso de conteúdo local em relaçăo à contrataçăo de determinado bem ou serviço sáo: inexistência de fornecedor brasileiro (I), propostas de fornecedores brasileiros com preços excessivos em relaçăo a congêneres năo brasileiros (II), propostas de fornecedores brasileiros com prazos de entrega excessivos em relaçâo a congêneres nâo brasileiros (III), e uso de nova tecnologia, năo existente no País (IV) (ANP, 2018).

A mencionada Resoluçăo ainda traz os critérios para definir o que é preço excessivo, um processo administrativo e claramente o juízo discricionário na revisăo e ajuste de novos percentuais de conteúdo local (ainda que justifique com base no interesse público). A norma em estudo teve embasamento na Resoluçấo nº 1 de 2018 do CNPE. 
Segundo dados da ANP (2018), foram realizados pedidos de isençăo referentes a 285 contratos (dos cerca de 300 possíveis), relativos a 349 blocos/campos. Destes, apenas 5 foram indeferidos, 15 estâo em análise e todos os outros foram aditados.

Há o reconhecimento formal estatal quanto a inadequaçâo de como a política de conteúdo local estava sendo imposta: em 2016 foi criado o Programa de Estímulo à Competitividade da Cadeia Produtivo, ao Desenvolvimento e ao Aprimoramento de Fornecedores do Setor de Petróleo e Gás Natural (PEDEFOR) através do Decreto $n^{0}$ $8.637 / 2016$.

Art. $1^{\circ}$ Ficainstituídoo Programa de Estímuloà Competitividade da Cadeia Produtiva, ao Desenvolvimento e ao Aprimoramento de Fornecedores do Setor de Petróleo e Gás Natural - Pedefor, com os seguintes objetivos: I - elevar a competitividade da cadeia produtiva de fornecedores no País; II - estimular a engenharia nacional; III - promover a inovaçăo tecnológica em segmentos estratégicos; IV - ampliar a cadeia de fornecedores de bens, serviços e sistemas produzidos no País; V - ampliar o nível de conteúdo local dos fornecedores já instalados; e VI - estimular a criaçáo de empresas de base tecnológica.

Os mecanismos (art. $2^{\circ}$ do Decreto $n^{\circ} 8.637 / 2016$ ) se operam através do incentivo aos fornecedores no país especificamente via engenharia desenvolvida localmente, desenvolvimento e inovaçăo, tecnológica geraçăo de empregos qualificados e estimula as exportaçóes. Bem como bonificaçāo a consórcios ou empresas que, no exercício das atividades de exploraçâo e produçăo de petróleo e gás natural, promovam no País.

Outro ponto problemático trazido pelo TCU (2016) foi a definiçăo complexa e excessivamente detalhada de itens e subitens os quais deveriam ser listados com respectivas porcentagens de conteúdo local obrigatório. O contratante deve preencher uma planilha complexa e detalhada contendo itens e subitens (cada indicaçáo tem peso diferente) comprados até atingir os percentuais estabelecidos no edital.

As exigências engessam a oferta de bens e serviços, que podem mudar ao longo do tempo, por causa da dinâmica do próprio mercado e da evoluçâo tecnológica. Na auditoria do TCU (2016) foram relatados em entrevistas que os contratantes indicam o consumo de certos itens e subitens que nâo mais refletem a realidade de contrataçōes do setor, todavia o fazem apenas para cumprir as formalidades exigidas pela licitaçáo.

Com base neste ponto crítico, o CNPE por meio da Resoluçâo n 7 de 2017 aplicável a partir da 14ª Rodadas de Licitaçăo (a partir de 2017), fixando o modelo de exigência global (nâo mais em itens e subitens), novos percentuais de conteúdo local, novas regras de aplicaçấo de multas (mais brandas), porém eliminou mecanismos de "Isençâo e Ajuste" (waiver).

Isso evidencia que a política de conteúdo local vem sofrendo consideráveis alteraçóes no sentido de flexibilizar as exigências e reduzir percentuais diante dos problemas encontrados na implementaçăo. Há a necessidade de traçar contornos da política visualizando o objetivo constitucional do desenvolvimento (art. $3^{\circ}$, II da CF) que dá sustentáculo à regulaçăo.

\subsection{PROPOSTAS}

No período de 2017 a 2019, a política de conteúdo local está sendo revista e alterada no sentido de reduzir sua amplitude, sendo incerto como ficará a sua regulaçấo nos 
próximos anos. Resta patente repensar a configuraçăo da intervençăo estatal no setor.

Carlos Xavier Junior (2012, p. 18) analisa que na formulaçăo de uma política de conteúdo local eficiente deve-se incluir minimamente fatores como financiamento, pesquisa e desenvolvimento, tributaçâo diferenciada e atençâo aos recursos humanos:

Ao analisar a literatura pertinente, acredita-se ainda que os princípios de uma política eficiente de CL devam incluir reflexóes sobre: 1) Financiamento: deve haver acompanhamento sobre a capacidade das empresas locais de captar recursos no mercado para atuarem na indústria de petróleo e gás, podendo inclusive haver linhas de financiamento públicas específicas para tal. 2) Política ativa de P\&D: as empresas devem ser incentivadas a investir em P\&D de modo a gerar transbordamentos na economia que superem as eventuais perdas de externalidades com o aumento do setor petrolífero. 3) Tributaçáo: os tributos pagos ao longo da cadeia pelos insumos nacionais devem criar situaçáo no mínimo idêntica entre os bens nacionais e estrangeiros, dado que haja disponibilidade de capital, tecnologia e interesse das firmas locais. 4) Recursos humanos: devem ser implementadas políticas de formaçáo e capacitaçáo de máo de obra qualificada para atuar nos projetos de E\&P, seja nas empresas petrolíferas, seja em suas fornecedoras, de modo a maximizar as externalidades advindas do processo de aprendizagem envolvido na atividade petrolífera em expansăo, além de gerar empregos para a măo de obra nacional.

Como proposta, o Estado pode conferir incentivos fiscais para aqueles que cumprem as exigências de conteúdo local, permitindo a isençâo ou reduçăo de tributos diretamente ao atendimento das metas da política.

Como forma incentivadora, também poderia ser pensada linha de crédito diferenciada destinada àquelas empresas que cumprem as exigências firmadas nas cláusulas de conteúdo local, através do Banco Nacional de Desenvolvimento Econômico e Social (BNDES). A criaçấo do Programa de Estímulo à Competitividade da Cadeia Produtivo, ao Desenvolvimento e ao Aprimoramento de Fornecedores do Setor de Petróleo e Gás Natural (PEDEFOR) pode abarcar a viabilidade dessas propostas.

A política de conteúdo local está sendo posta através de decretos, regulamentos e contratos, sendo "um verdadeiro monólogo do Poder Executivo" (BRASIL, Senado Federal, 2017, p. 41). O conjunto normativo é praticamente infralegal, sem possuir densidade suficiente para a definiçăo de uma política de conteúdo local. Săo duas perspectivas: por um lado há a facilidade de alteraçâo e consequente acompanhamento dinâmico das mudanças políticas, sociais, tecnológicas e negociais; por outro lado, regras mais estáveis como a lei, proporcionam maior previsibilidade em uma atividade que é desenvolvida por décadas (BRASIL, Senado Federal, 2017).

Assim, há a necessidade de achar um ponto de equilíbrio entre adaptabilidade e densidade normativa. É necessário existir segurança jurídica para atrair investimentos, previsibilidade da norma para operar, inclusive abrindo o seguinte questionamento: quais sâo os limites dessa política?

O Relatório do Senado Federal sobre conteúdo local (2017, p. 40) conclui a partir das diretrizes que tratamento legal do tema deveria se pautar:

Questōes importantes devem ser postas quanto à definiçáo de um marco legal, a exemplo: Ela terá caráter punitivo ou de incentivos? Percentuais mínimos de conteúdo local devem ser definidos pela via legal ou em sua regulamentaçăo? A 
efetividade permanece caso sejam definidos apenas índices globais ou é necessário definir subíndices? Qual a métrica a ser utilizada? Essa métrica é efetiva para garantir a implementaçấo de uma política industrial? Como definir a governança de forma a impedir que interesses diversos desviem os objetivos da política?

O ano de 2017 foi um marco para repensar a política de conteúdo local, uma vez que foi nesse ano que houve efetivamente mobilizaçōes dentro do Poder Legislativo para dar tratamento legal ao tema.

Em destaque temos o Projeto de Lei do Senado n² 218, de 2017, o qual procura dotar a política de conteúdo local de diretrizes e objetivos para atingir as metas que se destina: o projeto de lei fixa percentuais mínimos globais (70\% para etapa de exploraçâo e $75 \%$ na etapa de desenvolvimento), elenca de forma simplificada os bens e serviços, veda o uso do conteúdo local como critério de julgamento da seleçấo da melhor oferta nos processos de licitaçăo, legaliza o waiver (se inexistente fornecedor nacional, preço e prazo excessivo comparado ao mercado internacional, e ausência de tecnologia) e prevê multa administrativa de 30\% (trinta por cento) até 60\% (sessenta por cento) do valor nâo realizado do conteúdo local mínimo (BRASIL, Senado Federal, 2017).

Por sua vez, na Câmara dos Deputados há o Projeto de Lei nº 9.302/2017 que propóe fixar percentuais globais no mínimo de 18\% para fase de exploraçấo, e para fase de desenvolvimento $25 \%$ para serviços e $40 \%$ para bens (com três áreas específicas: construçăo de poço, unidade estacionária de produçăo e sistema de coleta e escoamento), quando tratar do regime de partilha de produçăo. Exploraçăo sob o regime de concessăo, se em terra, percentual global de 50\% tanto na fase de exploraçăo como na fase de desenvolvimento (seja bens ou serviços); se o bloco é situado no mar, percentual mínimo global de 18\% na fase de exploraçăo e variaçăo entre 25\% e 40\% (a depender das áreas específicas citadas) para fase de desenvolvimento. O percentual oferecido durante a licitaçâo nâo é adotado como critério para vencer a disputa (BRASIL, Câmara dos deputados, 2017).

A multa prevista no Projeto de Lei no 9.302/17 depende do percentual náo atingido. Se o percentual de conteúdo local náo realizado for inferior $65 \%$ do valor oferecido, a multa será de $60 \%$ sobre o valor do conteúdo local nâo-realizado. Se o percentual de conteúdo local náo realizado for igual ou superior a $65 \%$ do valor oferecido, a multa será crescente, partindo de $60 \%$ e atingindo $100 \%$ do valor do conteúdo local oferecido, no caso de o percentual de conteúdo local náo-realizado ser de 100\%. Náo há previsáo para exoneraçăo da obrigaçăo (BRASIL, Câmara dos Deputados, 2017).

Por sua vez, o Projeto de Lei n 7.401/2017 que tramita na Câmara de Deputados determina que o contratado deverá cumprir conteúdo local global năo inferior a 30\% (trinta por cento) para a fase de exploraçăo e nâo inferior a 50\% (cinquenta por cento) em cada etapa de desenvolvimento da produçấo. O Projeto prevê ainda a possibilidade do Poder Concedente exigir o cumprimento de conteúdos locais específicos para sistemas, subsistemas e itens, adicionalmente ao cumprimento dos conteúdos globais (BRASIL, Câmara dos Deputados, 2017).

O Projeto de Lei n 7.401/2017 permite a exoneraçăo (waiver) nas mesmas condiçôes Projeto de Lei do Senado n 218/2017: se inexistente fornecedor nacional, preço e prazo excessivo comparado ao mercado internacional, e tecnologia năo ofertada com conteúdo local. 
Neste projeto as multas săo calculadas sobre o valor monetário descumprido, aplicando-se o percentual de $50 \%$ (cinquenta por cento), caso o descumprimento do conteúdo local seja inferior a 60\% (sessenta por cento); e, caso seja maior que $50 \%$ (cinquenta por cento), proporcionalmente ao percentual de descumprimento do conteúdo local superior a 60\% (sessenta por cento) até o limite de 100\% (cem por cento) (BRASIL, Câmara dos Deputados, 2017).

O processo legislativo procura trazer a transparência e objetividade quanto às regras e o impacto da regulaçáo, bem como permitir o diálogo de diversos setores na construçáo de uma norma unificada.

Outra questâo levantada pelo Relatório do Senado Federal (2017) foi a dúvida se a política de conteúdo local tem prazo definido ou nâo, cuja indefiniçăo expressa gera incertezas para o setor do petróleo e a indústria local, além de gerar problemas na competitividade. Parece ser mais adequado fixar prazo ao invés de deixar a vigência indefinida, posto que objetiva que indústria local alcance o grau de competitividade igualitária no mercado após o período de proteçáo legal conferida pela política.

No que tange à ausência de prazo definido de vigência da política de conteúdo local, dois pontos devem ser levados em consideraçáo: a reserva de mercado impacta na (in) eficiência da indústria e, ainda que seja atingida a eficiência pretendida, a proteçáo estatal pode gerar um lucro excessivo em detrimento da sociedade, captura de renda (BRASIL, Tribunal de Contas da Uniâo - TCU, 2016).

Por fim, é interessante pensar na criaçâo de um instituto semelhante a um Termo de Ajuste de Conduta (TAC) aplicável ao setor, com o fito de nâo aplicar sumariamente multas e puniçôes, permitindo o diálogo e a busca para adequaçăo de efetividade. Isso porque o Termo de Ajuste de Conduta é um modo pelo qual o autor da infraçâo tem uma nova oportunidade para cumprir as obrigaçôes estabelecidas, em funçăo da năo aplicaçâo da penalidade, sempre visando atender o bem maior do objeto do acordo, rápido e eficaz para soluçăo do problema, evitando desgaste (FONTES; SOUZA, 2007).

\section{CONCLUSÃO}

O desenvolvimento é um fenômeno complexo que permeia diversos âmbitos da vida social (desde a parte cultural, intelectual, infraestrutura até a liberdade, por exemplo), muito além apenas do aspecto econômico e temporário, sendo um objetivo fundamental da República brasileira (art. $3^{\circ}$ da CF) com necessidade de concretizaçáo. A Constituiçấo Federal nâo aborda mandamentos, direitos, palavras, expressóes em văo: é o projeto de sociedade, guia que vincula a atuaçăo de todos.

A flexibilizaçăo do monopólio da Uniâo no que tange às atividades relacionadas ao petróleo veio acompanhada de uma regulamentaçăo que também pudesse impactar no desenvolvimento social. A inspiraçăo internacional, especialmente a norueguesa, serviu de espelho para a formulaçâo de uma política energética que contribuísse no desenvolvimento da indústria e reflexos sociais como preceituado na Constituiçăo Federal, o estímulo ao conteúdo local (em que pese o questionamento dessa política intervencionista no âmbito da OMC). 
Inicialmente, logo após a promulgaçăo da Emenda Constitucional nº 9 de 1995, veio a disciplina da Lei $n^{\circ}$ 9.478/1997 a qual criou o Conselho Nacional de Política Energética (CNPE) e Agência Nacional do Petróleo, Gás Natural e Bicombustíveis (ANP), órgăos essenciais para a regulamentaçấo e formulaçăo da política do setor. O instituto jurídico do conteúdo local foi gradualmente ganhando contornos ao longo do tempo, a cada exigência nas rodadas de licitaçăo promovidas pela ANP.

A cada rodada licitatória, o conteúdo local foi sendo mais estruturado como uma política industrial e com expansâo de suas dimensôes. O que antes era opcional, apenas mais um critério para vencer a licitaçăo, foi tornando-se obrigatório e com percentuais mais elevados. A Lei n 12.276/2010 apesar de ter o principal escopo de regulamentar o Pré-sal, consolida o conteúdo local, conceituando legalmente o instituo e determinando como atribuiçăo do CNPE o incremento dos índices mínimos de conteúdo local (com apoio da ANP).

A regulamentaçâo do setor, sobretudo de conteúdo local, foi tornando-se mais complexa, por exemplo, com o Sistema de Certificaçăo.

Independente da consolidaçâo de uma política industrial e a vigência da normatividade que a embasa, é necessário verificar os resultados colhidos da implementaçấo, a eficiência da regulaçăo estatal sem perder de vista o objetivo pretendido. No que diz respeito aos ditames constitucionais e a noçăo de desenvolvimento discutida, a política de conteúdo falha quando a blindagem regulatória permite que a indústria pratique preços elevados, com maior demora no prazo de entrega e atraso tecnológico frente aos concorrentes internacionais. Sâo problemas de competitividade identificados nâo só pelo setor que diariamente sente a rigidez da regulamentaçâo, mas por um órgáo oficial da Uniăo, como o TCU, por meio de uma auditoria técnica.

Nâo obstante, os problemas estruturais como falta de prazo de vigência, ausência de regulamentaçâo por meio de lei específica e caráter essencialmente punitivista devem ser sanados para que o objetivo de desenvolvimento social nâo seja desvirtuado, representando uma proteçăo arbitrária de grupos atuantes na indústria.

A estruturaçăo devida de uma política industrial passa pela avaliaçăo dos resultados da implementaçăo, identificaçăo dos problemas e reformulaçăo objetivando o aprimoramento conforme o propósito intencionado. Nesse contexto, a reestruturaçăo da política de conteúdo local para incluir incentivos para cumprimento de regras e metas ao invés apenas de puniçâo em caso de descumprimento, normatividade clara e simples, prazo de vigência definido, alternativas para readequaçăo de cumprimento ao invés de apenas aplicaçăo de multa como opçâo (TAC) e em ultima ratio, a possibilidade de isençăo ou renegociaçấo caso comprovadamente a indústria nacional nâo tenha a capacidade de suprir a demanda com eficiência. Esse conjunto de reestruturaçóes passa por um tratamento legal da matéria.

A reestruturaçăo nâo pode deixar a margem as políticas voltadas para a melhoria da competitividade da indústria nacional, sendo importante inciativa o PEDEFOR criado em 2016. Se o objetivo real é o desenvolvimento da indústria nacional e a longo prazo a competiçăo em nível internacional, o problema năo está em cumprir formalmente os percentuais de consumo de conteúdo local, mas como indústria nativa está suprindo as demandas do setor. Isso pode culminar no foco estratégico de setores específicos que serâo o ponto forte do Brasil e referência no mercado global (o que implica em desenvolvimento de ciência, tecnologia e inovaçăo), diversamente do atual modelo de suprimento 
das mais variadas demandas do mercado interno por força de imposiçăo estatal.

Năo basta a realizaçăo de alteraçōes mínimas e frequentes (o que gera insegurança jurídica) para tentar dar viabilidade de uma política industrial como está sendo posta. A restruturaçâo da política de conteúdo local como uma política industrial com bases densas, se torna eficaz ferramenta em prol do desenvolvimento objetivado pela Constituiçâo Federal.

\section{REFERÊNCIAS}

Agência Nacional do Petróleo, Gás Natural e Biocombustíveis - ANP. Nota técnica $\mathbf{n}^{\circ}$ 020/2018/SCL. Aferiçấo de Conteúdo Local na etapa de desenvolvimento da fase de produçấo. 2018. Disponível em:

http://www.anp.gov.br/images/central-de-conteudo/notas-estudos-tecnicos/notas-tecnicas/nota-tecnica-20-2018-sim.pdf. Acesso em 10 ago. 2019.

Agência Nacional do Petróleo, Gás Natural e Biocombustíveis - ANP. Resoluçăo n 19 de 2013 - Certificaçâo de Conteúdo Local. DOU 17.6.2013 Disponível em: http://legislacao. anp.gov.br/?path=legislacao-anp/resol-anp/2013/junho\&item=ranp-19--2013. Acesso em: 02 set. 2019.

Agência Nacional do Petróleo, Gás Natural e Biocombustíveis - ANP. Resoluçăo ANP n 25/2016 - Acreditaçâo de Organismos de Certificaçâo de Conteúdo Local. DOU 8.6.2016. Disponível em: http://legislacao.anp.gov.br/?path=legislacao-anp/resol-anp/2016/junho\&item=ranp-25--2016. Acesso em: 02 set. 2019.

Agência Nacional do Petróleo, Gás Natural e Biocombustíveis - ANP. Resoluçăo da ANP 27 de 2016 - Relatórios de Conteúdo Local. DOU 17.6.2016. Disponível em: http://legislacao.anp.gov.br/?path=legislacao-anp/resol-anp/2016/junho\&item=ranp-27--2016. Acesso em: 02 set. 2019.

AgênciaNacionaldoPetróleo,GásNaturaleBiocombustíveis-ANP.ResoluçáoANP726/2018 - DOU 12.4.2018 - republicada DOU 16.4.2018 - retificada DOU 16.4.2018. Estabelece os critérios, requisitos e procedimentos aplicáveis à Isençăo de cumprimento da obrigaçăo de Conteúdo Local. Disponível em: http://legislacao.anp.gov.br/?path=legislacao-anp/resol-anp/2018/abril\&item=res-726-2019. Acesso em: 02 set. 2019.

Agência Nacional do Petróleo, Gás Natural e Biocombustíveis - ANP. Brasil 14ª Rodada: licitaçōes de petróleo e Gás.2017 Disponível: http://www.anp.gov.br/images/Palestras/Seminario_ Juridico14/CCL_Apresenta\%C3\%A7ao_R14_21072017.pdf. Acesso em: 02 set. 2019.

ALMEIDA, Edmar de; LOSEKANN, Luciano; VITTO, Adrian Clavijo. Custos e benefícios da atual política de conteúdo local. Rio de Janeiro: Cooperaçấo e Pesquisa IBP - UFRJ, 2016. Disponível em: https://www.ibp.org.br/personalizado/uploads/2016/09/2016_ TD_Custos-e-Benef\%C3\%ADcios-da-Pol\%C3\%ADtica-Conte\%C3\%BAdo-Local.pdf. Acesso em: 15 maio 2019. 
ALMEIDA, Raquel Filgueiras de. Políticas de conteúdo local e setor para-petroleiro: uma análise comparativa entre brasil e noruega. Mestrado (Pós-graduaçâo em Planejamento Energético), COPPE da Universidade Federal do Rio de Janeiro. Rio de Janeiro: 2015.

BRASIL. Constituiçăo da República Federativa do Brasil de 1988. Disponível em: http://www. planalto.gov.br/ccivil_03/constituicao/constituicaocompilado.htm. Acesso em: 10 ago. 2019.

BRASIL. Decreto $\mathbf{n}^{\circ}$ 8.637, de 15 de janeiro de 2016. Institui o Programa de Estímulo à Competitividade da Cadeia Produtiva, ao Desenvolvimento e ao Aprimoramento de Fornecedores do Setor de Petróleo e Gás Natural. Disponível em: http://www.planalto. gov.br/ccivil_03/_Ato2015-2018/2016/Decreto/D8637.htm. Acesso em: 10 set. 2019.

BRASIL. Lei $\mathbf{n}^{\mathbf{9}} \mathbf{9 . 4 7 8}$, de 6 de agosto de 1997. Dispóe sobre a política energética nacional, as atividades relativas ao monopólio do petróleo, institui o Conselho Nacional de Política Energética e a Agência Nacional do Petróleo e dá outras providências. Disponível em: http://www.planalto.gov.br/ccivil_03/LEIS/L9478.htm. Acesso em: 15 set. 2019.

BRASIL. Lei n 12.351, de 22 de dezembro de 2010. Dispóe sobre a exploraçâo e a produçâo de petróleo, de gás natural e de outros hidrocarbonetos fluidos, sob o regime de partilha de produçăo, em áreas do pré-sal e em áreas estratégicas; cria o Fundo Social - FS e dispóe sobre sua estrutura e fontes de recursos; altera dispositivos da Lei n 9.478, de 6 de agosto de 1997; e dá outras providências. Disponível em: http://www.planalto. gov.br/ccivil_03/_Ato2007-2010/2010/Lei/L12351.htm. Acesso em: 02 set. 2019.

BRASIL. Lei $\mathbf{n}^{0} \mathbf{1 2 . 2 7 6}$, de $\mathbf{3 0}$ de junho de 2010. Autoriza a Uniăo a ceder onerosamente à Petróleo Brasileiro S.A. - PETROBRAS o exercício das atividades de pesquisa e lavra de petróleo, de gás natural e de outros hidrocarbonetos fluidos de que trata o inciso I do art. 177 da Constituiçăo Federal, e dá outras providências. Disponível em: http://www. planalto.gov.br/ccivil_03/_ato2007-2010/2010/lei/112276.htm. Acesso em: 02 set. 2019.

BRASIL. Senado Federal. Projeto de Lei do Senado n² 218, de 2017. Dispóe sobre o conteúdo local obrigatório nas aquisiçóes de bens e serviços para as atividades, em todos os regimes, de exploraçáo e produçăo de petróleo, gás natural e outros hidrocarbonetos fluidos e dá outras providências. Disponível em: https://www12.senado.leg.br/ecidadania/visualizacaomateria?id=129960. Acesso em: 10 set. 2019.

BRASIL. Câmara dos deputados. Projeto de Lei 9.302/17. Estabelece a política de conteúdo local para as atividades de exploraçâo e produçáo de petróleo, gás natural e outros hidrocarbonetos fluidos. Disponível em: https:/www.camara.leg.br/proposicoesWeb/ fichadetramitacao?idProposicao=2165807. Acesso em: 10 set. 2019.

BRASIL. Câmara dos deputados. Projeto de Lei 7.401/17. Estabelece a política de conteúdo local para as atividades de exploraçâo e produçâo de petróleo, gás natural e outros hidrocarbonetos fluidos. Disponível em: https://www.camara.leg.br/proposicoesWeb/ fichadetramitacao?idProposicao=2129296. Acesso em: 10 set. 2019. 
BRASIL. Senado Federal. Relatório n - CAE, 2017 - Conteúdo local nos setores de petróleo e gás natural, telecomunicaçōes, defesa e transportes. Brasília, 2017. Disponível em: http://legis.senado.leg.br/sdleg-getter/documento/download/d8ae46a5-255a-431a-b4ca-1e218962e4cf. Acesso em: 15 maio 2019.

BRASIL, Tribunal de Contas da Uniăo. Auditoria Operacional. Avaliaçâo da Sistemática Vigente da Política de Conteúdo Local. Análise das Implicaçōes e dos Impactos da Ausência de Regulamentaçăo do Instrumento de Waiver. Determinaçôes e Recomendaçōes. Processo: TC 030.511/2015-1. Disponível em: https://pesquisa.apps. tcu.gov.br/\#/documento/acordao-completo/*/KEY:ACORDAO-COMPLETO2101076/ DTRELEVANCIA\%20desc/0/sinonimos\%3Dfalse. Acesso em: 3 maio 2019.

BECKER, Dinizar F.; WITTMANN, Milton Luiz (org.). Desenvolvimento Regional: abordagens interdisciplinares. Santa Cruz. EDNISC, 2003.

BULOS, Uadi Lammêgo. Curso de Direito Constitucional. 9. ed. Săo Paulo: Saraiva, 2015.

CABRAL, Indhira de Almeida. Normas tributárias indutoras na concretizaçăo do princípio constitucional da reduçăo das desigualdades sociais e regionais. Dissertaçâo (Mestrado em Direito) - Faculdade de Direito da Universidade Federal do Rio Grande do Norte. Rio Grande do Norte: 2008.

CHAMBRIARD, Magda. Perspectivas para o setor de óleo e gás brasileiro e as rodadas de licitaçōes da ANP. ANP, 2013.

COMPARATO, Fábio Konder. Para viver a democracia. Sáo Paulo: BRASILIENSE, 1989.

FABRÍCIO, André Rodrigues. 0 objetivo constitucional de desenvolvimento e o instrumento jurídico normativo do conteúdo local na indústria do petróleo. Dissertaçâo (Mestrado em Direito) - Faculdade de Direito da Universidade Federal do Rio Grande do Norte. Rio Grande do Norte: 2014.

FEIJÓ, Ricardo. Desenvolvimento Econômico: modelos, evidências, opçōes políticas e o caso brasileiro. Săo Paulo: Atlas, 2007.

FIGUEIREDO, Natália. Acordo TRIMS: flexibilizaçăo ou năo? Política de conteúdo local, processo produtivo básico (PPB) e os desafios para a indústria brasileira e a integraçâo latino-americana. Brasília. UniCEUB, Revista de Direito internacional, 2016. Disponível em: https://www.publicacoesacademicas.uniceub.br/rdi/article/download/3943/pdf. Acesso em: 07 de set. 2019

FORMAN, John. Conteúdo local na indústria do petróleo e gás no brasil. Sâo Paulo: FGV, 2016. Disponível em: https://bibliotecadigital.fgv.br/dspace/bitstream/handle/10438/19216/John\%20Forman_agosto2016.pdf. Acesso em: 15 maio 2019

FRANÇA, Phillip Gil. Objetivos fundamentais da República, escolhas públicas e políticas públicas: Caminhos de Concretizaçăo dos Benefícios Sociais Constitucionais. 1ed.Curitiba: Clássica Editora, 2014, v. 25, p. 230-244. Disponível em: http://www. 
publicadireito.com.br/artigos/?cod=534488729ab74ff0. Acesso em: 15 maio 2019.

FURTADO, Celso. Introduçăo ao desenvolvimento: enfoque histórico-estrutural. Sáo Paulo: Paz e Terra, 2000.

GRAU, Eros. A ordem econômica na Constituiçăo de 1988: interpretaçăo e crítica. Sâo Paulo: Malheiros. 2010.

IBP - Instituto Brasileiro de Petróleo, Gás e Biocombustíveis. Agenda prioritária da indústria de petróleo, gás e biocombustíveis 2019-2022. Rio de Janeiro: IBP, 2019. Disponível em: http://ibp-5.rds.land/agenda-da-industria-2019-2022-petroleo-gas-e-biocombustiveis. Acesso em: 15 maio 2019.

LUMBRERAS; Marlúcia Junger, PIQUET, Rosélia. Avanços e retrocessos na Política de Conteúdo Local brasileira. Boletim Petróleo, Royalties e Regiăo - Campos dos Goytacazes/RJ - Ano XVI, nº 60 - agosto / 2018. Disponível em: https://royaltiesdopetroleo.ucam-campos.br/wp-content/uploads/2018/08/Ucam-Boletim-Artigo-1.pdf. Acesso em: 15 maio 2019.

MORAES, Alexandre. Constituiçăo do Brasil interpretada e legislaçăo constitucional. Sâo Paulo: Atlas 2007.

QUINTANS, Luiz Cezar P. Direito do Petróleo: Conteúdo Local. Rio de Janeiro: IBP/ Freitas Bastos, 2010.

SANÁBIO, Mariana Frias. Modelos de exploraçăo de petróleo. PUC: Rio de Janeiro, 2009

SEN, Amartya Kumar. Desenvolvimento como liberdade. traduçăo Laura Teixeira Motta; revisăo técnica Ricardo Doniselli Mendes. Sâo Paulo: Companhia das Letras, 2008.

SILVA, José Afonso. Comentário contextual à Constituiçăo. 6. ed. Săo Paulo: Malheiros, 2009.

SOUZA, Demétrius Coelho; FONTES, Vera Cecília Gonçalves. Compromisso de Ajustamento de Conduta. Revista Jurídica da UniFil, ano IV, n. 4, 2007.

SZEZERBICKI, A. S. Os princípios gerais da atividade econômica brasileira: avanços e efetividade desde a Constituiçăo Federal de 1988. Eptic On-Line (UFS), v. XI, p. 01, 2009. Disponível em: http://eptic.com.br/wp-content/uploads/2014/12/textdisc6.pdf. Acesso em: 01 set. 2019.

XAVIER, Carlos Eduardo Ramos. Políticas de conteúdo local no setor petrolífero: o caso brasileiro e a experiência internacional. Rio de Janeiro: IPEA, 2012. Disponível em: http:// www.ipea.gov.br/portal/index.php?option=com content\&view=article\&id=16369. Acesso em: 15 maio 2019.

Recebido em: 22 de julho de 2019.

Aprovado em: 3 de setembro de 2019. 